Evaluation of pediatric head trauma in the emergency department

Gessler, Peter

DOI: https://doi.org/10.1007/s00431-005-0020-0

Posted at the Zurich Open Repository and Archive, University of Zurich ZORA URL: https://doi.org/10.5167/uzh-156599

Journal Article

Published Version

Originally published at:

Gessler, Peter (2006). Evaluation of pediatric head trauma in the emergency department. European Journal of Pediatrics, 165(3):141.

DOI: https://doi.org/10.1007/s00431-005-0020-0 


\section{Evaluation of pediatric head trauma in the emergency department}

Received: 5 August 2005 / Accepted: 8 August 2005 / Published online: 26 November 2005

(C) Springer-Verlag 2005

Head trauma is one of the most common childhood injuries. More than $80 \%$ of these injuries are mild, but traumatic brain injury is the leading cause of death due to trauma in children. Skull radiographs and computed tomography (CT) can accurately identify fractures and intracranial complications, respectively. Nevertheless, their indiscriminate use wastes resources and raises costs. Guidelines have been published for the management of minor closed head injury in children $2-20$ years of age $[1,6]$ and for infants less than 2 years old $[6,9]$. Acute evaluation of the headinjured child requires careful history-taking with a focus on the mechanism and biomechanics of the injury, and a physical examination that includes a complete neurological examination. Issues in the management of the pediatric patient with head trauma include the need for cranial CT, hospitalization, outpatient follow-up, and a consideration of the possibility of child abuse [3, 7].

The study of Da Dalt et al. [4] in this issue addresses whether clinical features of children with head trauma predict the risk of intracranial injury. A total of 3,806 children under the age of 16 years were enrolled in a prospective multicenter study in Italy. Based on the history and clinical examination, the children were classified into different risk categories and consecutive management - i.e., discharge, observation, admittance to the intensive care unit, or neurosurgery. Intracranial injury was diagnosed on CT (79 children underwent a $\mathrm{CT}$, and intracranial injury was identified in 22) and was assumed to be absent in the case of an uneventful course, as determined by a follow-up telephone call (about 10 days after discharge), or the lack of a readmission to hospital. The large majority of children had

P. Gessler $(\bowtie)$

Division of Pediatric Intensive Care Medicine \& Neonatology, University Children's Hospital,

Steinwiesstr. 75 ,

8032, Zurich, Switzerland

e-mail: peter.gessler@kispi.unizh.ch

Tel.: +41-44-2667111

Fax: +41-44-2667168 minor head trauma with asymptomatic presentation or with a history of only temporary loss of consciousness. This study emphasizes the practice that $\mathrm{CT}$ is rarely necessary in these children, but - and most importantly - only after careful clinical evaluation and a knowledge of the risk factors for intracranial injury $[2,5,6,8]$.

\section{References}

1. American Academy of Pediatrics (1999) The management of minor closed head injury in children. Committee on quality improvement, American academy of pediatrics, commission on clinical policies and research, and American academy of family physicians. Pediatrics 104:1407-1415

2. Arbogast KB, Margulies SS, Christian CW (2005) Initial neurologic presentation in young children sustaining inflicted and unintentional fatal head injuries. Pediatrics 116:180-184

3. Berger RP, Adelson PD (2005) Evaluation and management of pediatric head trauma in the emergency department: current concepts and state-of-the-art research. Clin Pediatr Emerg Med $6: 8-15$

4. Da Dalt L, Marchi AG, Laudizi L, Crichiutti G, Messi G, Pavanello L, Valent F, Barbone F Predictors of intracranial injuries in children after blunt head trauma. Eur J Pediatr

5. Dunning J, Batchelor J, Stratford-Smith P, Teece S, Browne J, Sharpin C, Mackway-Jones K (2004) A meta-analysis of variables that predict significant intracranial injury in minor head trauma. Arch Dis Child 89:653-659

6. Kamerling SN, Lutz N, Posner JC, Vanore M (2003) Mild traumatic brain injury in children: practice guidelines for emergency department and hospitalized patients. Pediatr Emerg Care 19:431-440

7. Keenan HT, Runyan DK, Marshall SW, Nocera MA, Merten DF (2004) A population-based comparison of clinical and outcome characteristics of young children with serious inflicted and noninflicted traumatic brain injury. Pediatrics 114:633-639

8. Palchak MJ, Holmes JF, Vance CW, Gelber RE, Schauer BA, Harrison MJ, Willis-Shore J, Wootton-Gorges SL, Derlet RW, Kuppermann N (2004) Does an isolated history of loss of consciousness or amnesia predict brain injuries in children after blunt head trauma? Pediatrics 113:e507-e513

9. Schutzman SA, Barnes P, Duhaime AC, Greenes D, Homer C, Jaffe D, Lewis RJ, Luerssen TG, Schunk J (2001) Evaluation and management of children younger than two years old with apparently minor head trauma: proposed guidelines. Pediatrics 107:983-993 